\title{
Non-enzymatic glycation of human albumin does not alter its palmitate binding
}

\author{
M.H. Murtiashaw and K.H. Winterhalter \\ Biochemistry Laboratory I, Eidgenössische Technische Hochschule, Zürich, Switzerland
}

Summary. The study described here makes use of a new technique to assess the level of non-enzymatic glycosylation (glycation) by purified radioactively labelled glucose. Glycation up to $3 \mathrm{molglc} / \mathrm{mol}$ protein of human serum albumin, in contrast to previous reports, did not affect the binding of up to 2 mol palmitate, which was reached at a ratio of 7.5 palmitate/ HSA. The uptake of palmitate from albumin by either erythrocytes or HL-60 cells also was not influenced by glycation of $3 \mathrm{~mol}$ glucose $/ \mathrm{mol}$ protein. The distribution of palmitate into neutral lipids, phospholipids, or the palmitate designated for oxidation was likewise not influenced. This suggests that levels of albumin glycation likely to be encountered in the blood of diabetic subjects (up to $1 \mathrm{molglc} / \mathrm{mol} \mathrm{HSA}$ ) do not affect fatty acid utilization.

Key words: Non-enzymatic glycosylation, albumin, diabetes, fatty acids.
Non-enzymatic glucosylation (glycation) is a well documented modification of proteins resulting from the covalent attachment of glucose to amino groups in protein $[1,2]$.

The glycation level of a protein in vivo depends on both the prevailing glucose concentration and the halflife or span of the protein, given the time of exposure to glucose. Thus, glycation has been detected in several long-lived proteins [e.g. lens crystallines [3], basement membranes collagen [4]] and many blood proteins (fibrin [5], low density lipoproteins [6], albumin, haemoglobin in vivo in healthy subjects [review, 7]). The levels of glycation are elevated in diabetes mellitus.

Non-enzymatic glycation could affect protein function. It has been noted that glycated lens crystallines are less soluble [3], that glycated low density lipoproteins have an altered rate of catabolism [6], and that glycated haemoglobin has an altered ability to bind oxygen and 2,3-diphosphoglycerate [8]. The physiopathological implications of these altered properties are not yet clear.

The major glycated protein in blood plasma is albumin. This globular protein is the primary contributor to plasma oncotic pressure, and serves as a plasma carrier for many drugs and metabolites. It is the main transport molecule for free fatty acids in blood. In a preliminary report, Reed et al. [9] found that the initial binding site of palmitate in bovine albumin was in a cleft surrounded by amino acids 113-122, 348-350 and
454-504. Thus, the palmitate binding site may be adjacent to or may overlie the lysine residue 525 , which is putatively the first lysine to be glycated in human albu$\min [10]$.

In this study we examine the effect of glycation of human albumin on its ability to bind palmitate and to deliver palmitate to cells.

\section{Materials and methods}

Human albumin, Fraction V, essentially fatty acid free, and crystalline palmitic acid were obtained from Sigma Chemical Co (St Louis, MO, USA). ${ }^{1-14} \mathrm{C}$-palmitic acid, $54 \mathrm{Ci} / \mathrm{mol}$, was purchased from $\mathrm{New}$ England Nuclear (Boston, MA, USA). Dowex 2, X8, 20/50 mesh was purchased from Fluka AG (Buchs, Switzerland). Alumina N (neutral aluminium oxide), activity 1 , was obtained from Woelm Pharma, Eschwege, FRG. For scintillation counting, RIA - Luma cocktail and Luma - Solv (Lumac/3M, Schaesberg, The Netherlands) were used. All other chemicals used in these studies were of the highest purity available.

\section{Procedures}

Non-enzymatically glycated albumin was prepared as described previously [12]. Albumin (25-100 mg) (HSA) was mixed with glucose in $0.15 \mathrm{~mol} / 1$ sodium phosphate buffer, $\mathrm{pH} 7.4$, containing $0.01 \%$ gentamycin sulfate in a final volume of $1.0 \mathrm{ml}$. Glucose concentrations ranged from $0.05-0.5 \mathrm{~mol} / 1$. In control samples, glucose was replaced by an equal concentration of sorbitol. Samples were incubated at $37^{\circ} \mathrm{C}$ in sealed Eppendorf centrifuge tubes for up to 4 days. Under 
these conditions, human albumin is glucated at a rate of $0.0025 \mathrm{~mol}$ glucose/mol albumin per day per $\mathrm{mmol} / \mathrm{l}$ glucose in the incubation mixture.

In order to test for the level of glycation, $100 \mu$ l aliquots of each mixture were incubated in parallel at $37{ }^{\circ} \mathrm{C}$ with $\mathrm{U}-{ }^{14} \mathrm{C}$-glucose previously purified by high performance liquid chromatography [12]. At the end of the incubation, the radiolabeled sample was diluted with $5.0 \%$ acetic acid to a final volume of $500 \mu \mathrm{l}$ and incubated at $37^{\circ} \mathrm{C}$ for $30 \mathrm{~min}$ in order to discharge labile aldmine adducts on the albumin. This procedure leaves only the ketoamine derivative intact. The protein sample was then applied to a Sephadex G-25 column $(24 \times 1 \mathrm{~cm})$ equilibrated with Dulbecco's phosphate buffered saline (PBS), $\mathrm{pH} 7.4$, at $5^{\circ} \mathrm{C}$. Fractions $(40 \times 0.5 \mathrm{ml}$ at a flow rate of $0.5 \mathrm{ml} / \mathrm{min})$ were collected directly into $5 \mathrm{ml}$ scintillation vials and mixed with $4 \mathrm{ml}$ RIA-Luma. The entire column profile was counted for radioactivity. Mol glucose/per mol albumin was calculated from the percentage of total column radioactivity eluting at the void volume, the specific activity of the glucose in the original incubation, and the protein concentration.

\section{Preparation of palmitate/albumin complexes}

Palmitate/HSA complexes were formed using the two phase system described by Spector [13]. In all studies, both control and glucosylated albumin preparations were first subjected to mild acidic incubation followed by G-25 chromatography to remove both free glucose and glucose released from breaking the aldimine linkage. Only the ketoamine derivative of glycated albumin was thus obtained. One $\mathrm{ml}$ of $1{ }^{14} \mathrm{C}$-palmitate $(0.1-0.2 \mathrm{mmol} / \mathrm{l})$ in heptane and $1 \mathrm{ml}$ control or glycated human albumin $(0.02-0.1 \mathrm{mmol} / 1)$ in PBS were mixed together. The fatty acid: HSA ratio varied from 1.0-10.0. The samples were incubated in a shaking water bath for up to $24 \mathrm{~h}$. At intervals, samples were removed from the water bath, centrifuged, and duplicate aliquots $(50-100 \mu 1)$ were removed from each phase using a microliter syringe. The samples were counted for radioactivity to determine distribution of palmitate in each phase. Palmitate binding to protein was calculated from the protein concentration of the aqueous phase and the specific activity of the $1-{ }^{14} \mathrm{C}$-palmitate. Calculations were verified by a colorimetric assay for fatty acids [14]. To avoid introducing error due to volume changes, a separate sample was prepared for each time point in the kinetic studies. In each study, a sample containing equimolar palmitate in heptane mixed with PBS was included to determine the solubility of palmitate alone in the aqueous phase. In the palmitate concentrations used in this study, less than $0.5 \%$ of palmitate was soluble in PBS.

\section{Incubation of palmitate/HSA complexes with cells}

Palmitate/HSA complexes in PBS were subjected to mild vacuum for $1 \mathrm{~min}$ at room temperature to evaporate any traces of heptane. In all incubations the palmitate: HSA ratio was $2: 1$, and all glycated albumin preparations contained $3 \mathrm{~mol} \mathrm{glc} / \mathrm{mol}$ protein.

\section{Erythrocyte incubations}

Erythrocytes were prepared from fresh human blood drawn into heparin. The red cells were washed three times with isotonic aline and then resuspended in isotonic PBS. Aliquots of the erythrocyte suspension $\left(2.0-2.4 \times 10^{9} \mathrm{cel} l \mathrm{~s} / 500 \mu \mathrm{l}\right)$ were mixed with $500 \mu \mathrm{l}$ aliquots of the palmitate/HSA complex. The final palmitate concentration was $25 \mu \mathrm{mol} / \mathrm{l}$. The cells were incubated at $37^{\circ} \mathrm{C}$ for up to $1 \mathrm{~h}$ and thereafter washed 3 times with PBS prior to extraction of total lipids.

\section{$H L-60$ cell incubations}

The HL-60 cell line was originally derived from the blood of a patient with promyelocytic leukaemia [15] and has been shown to transport and metabolize fatty acids [16]. Stock cultures were maintained in
Iscove's modified Dulbecco's medium (IMDM, Gibco AG, Basel, Switzerland) supplemented with $10 \%$ fetal bovine serum (Gibco), $2 \mathrm{mmol} / 1$ glutamine, $100 \mathrm{U} / \mathrm{ml}$ penicillin and $100 \mu \mathrm{g} / \mathrm{ml}$ streptomycin. They were passaged twice a week at a $1: 3$ to $1: 4$ split ratio and incubated in a humidified atmosphere of $5 \% \mathrm{CO}_{2}$ in air.

For incubations, $1 \times 10^{6}$ cells were mixed into fresh IMDM containing 10\% fetal bovine serum ( $50 \mathrm{~mol} / \mathrm{l}$ bovine albumin) to ensure linear uptake and utilisation [16] and $25 \mathrm{~mol} / 11-{ }^{14} \mathrm{C}$-palmitate bound to human albumin in $(12 \mathrm{~mol} / \mathrm{l})$ in a final volume of $1.0-1.5 \mathrm{ml}$. Experiments in the absence of fetal bovine serum demonstrated no difference between uptake of palmitate from control and glycated human albumin. In these latter experiments the uptake was, however, not linear with time. Cells were incubated for up to $1 \mathrm{~h}$ at $37^{\circ} \mathrm{C}$ and then placed on ice to stop the reaction. After centrifugation the supernatant was collected and counted for radioactivity. The cells were washed 3 times with PBS and the lipids were extracted.

\section{Lipid extraction and analysis}

In both erythrocyte and HL-60 cell studies, total lipids were extracted and analyzed by ion exchange chromatography on alumina described by Morand et al. [16]. Washed erythrocytes or HL-60 cells were mixed with $2 \mathrm{ml}$ chloroform: methanol, $(1: 1, \mathrm{v}: \mathrm{v})$ at $60^{\circ} \mathrm{C}$ for $10 \mathrm{~min}$. After centrifugation, the pellet was discarded and $1 \mathrm{ml}$ chloroform and $750 \mu \mathrm{l}$ water were mixed with the supernatant. The samples were centrifuged to separate the phases, and the lower phase was collected and evaporated under a stream of $\mathrm{N}_{2}$. The dried extract was reconstituted into $500 \mu \mathrm{l}$ of $95: 5$ chloroform: methanol, and $100 \mu \mathrm{l}$ was counted to determine total palmitate uptake into cells.

Small columns containing $500 \mathrm{mg}$ of alumina were prepared in Pasteur pipets. The columns were washed first with methanol and then chloroform. Lipid extracts in 95:5 chloroform:methanol were applied to the columns. Neutral lipids were eluted with two ml 95:5 chloroform: methanol. Phospholipids were then eluted with $2 \mathrm{ml}$ of 1:1 chloroform:methanol. All fractions were eluted directly into small $5 \mathrm{ml}$ scintillation vials and counted for radioactivity in $4 \mathrm{ml}$ RIA-Luma. The free fatty acid pool was estimated from the counts in the original lipid extract that were retained on the alumina column.

The free palmitate pool was also measured directly using the anion exchange chromatographic method described by Kelley [17]. Dowex 2 , a strong anion exchange resin was prepared in the hydroxyl form by washing with $100 \mathrm{vol}$ of $5 \% \mathrm{NaOH}$. The resin was washed with water until neutral, then washed with isoproponal, and finally with hexane. The assay was placed in the vial and the total lipid extract in $1 \mathrm{ml}$ of hexane was added. The samples were mixed by swirling. After the beads had settled, the hexane layer was removed by vacuum aspiration. The resin was washed three times with $5 \mathrm{ml}$ portions of hexane. Five hundred $\mu \mathrm{l}$ of Luma/Solv, a quarternary ammonium base, was added to displace the fatty acid anion from the resin. Five hundred $\mu 1$ of isopropanol and $12 \mathrm{ml}$ of acidified scintillation fluid (95:5 RIA/Luma:0.IN HC1) were added to each vial. Before being counted, the samples were left overnight to allow chemiluminescence to subside. The presence of the resin beads and the traces of organic solvents introduced some quenching of counts, but samples usually exhibited $60-70 \%$ counting efficiency as determined by channels ratios. Despite these methodological problems, the two methods for measuring free fatty acids agreed within $20 \%$.

\section{Assay of palmitate oxidation}

HL-60 cells were incubated in vials fitted with a center well. One million cells were incubated at $37^{\circ} \mathrm{C}$ in $1 \mathrm{ml}$ of medium containing $12 \mu \mathrm{mol} / 1$ palmitate in a $2: 1$ palmitate: HSA complex. At the end of $60 \mathrm{~min}$ incubation, $300 \mu \mathrm{l} \mathrm{Luma} / \mathrm{Solv}$ was injected into the center well, and $500 \mu \mathrm{l}$ of $1 \mathrm{~N} \mathrm{HC1}$ was added to the cell suspension. Incubations in $37^{\circ} \mathrm{C}$ shaking water bath were continued for another hour to collect ${ }^{14} \mathrm{CO}_{2}$. The center wells were then placed in $30-\mathrm{ml}$ scintillation vials. Isopropanol $(250 \mu \mathrm{l}), 1 \mathrm{~N} \mathrm{HCl}, 250 \mu \mathrm{l}$, and RIA Luma $12-\mathrm{ml}$ scintillation cocktail were added to each vial. The samples were stored overnight before counting to allow chemiluminescence to subside. 

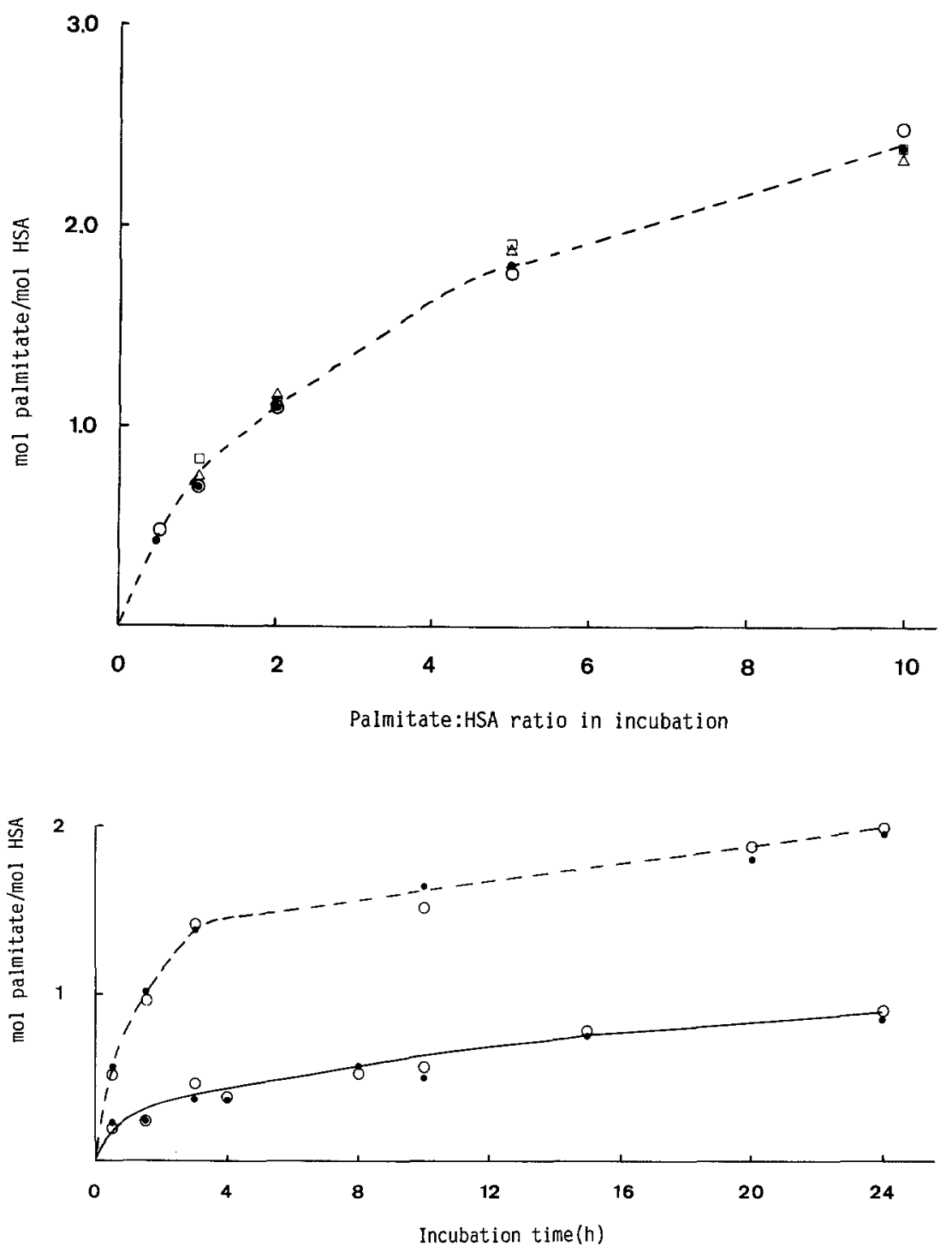

Fig. 1. The effect of palmitate: albumin ratio on the binding of palmitate to control and glycosylated albumin. $1 .{ }^{14} \mathrm{C}$-palmitate $(0.1-0.2 \mathrm{mmol} / 1$ in heptane), $6000 \mathrm{cpm} / \mathrm{nmol}$, and control or glucosylated albumin $(0.02-0.1 \mathrm{mmol} / 1$ in PBS) were incubated together for $24 \mathrm{~h}$. The volume of each phase was $1 \mathrm{ml}$, and the concentration of albumin or palmitate were adjusted to achieve the palmitate : albumin ratios indicated. Glucosylated albumins were prepared in vitro as described in Methods, control $\mathrm{HSA}, O 0.10 \mathrm{molglc} / \mathrm{mol} \mathrm{HSA}, \triangle 1.0 \mathrm{molglc} / \mathrm{mol}$ HSA, $\square 3 \mathrm{molglc} / \mathrm{mol}$ HSA
Fig. 2. The effect of glucosylation and fatty acid: protein ratio on the rate of palmitate binding to albumin. Heavily glucosylated albumin ( 3 molglc/ mol HSA) (O) and control (O) albumin in PBS $(40 \mathrm{nmol} / \mathrm{mol})$ were mixed with $1{ }^{14} \mathrm{C}$ palmitate $(4500 \mathrm{cpm} / \mathrm{nmol})$ in heptane, $40 \mathrm{nmol} / \mathrm{ml}$ or 200/nmol $\mathrm{ml}$ to achieve FA:: HSA ratios of $1: 1$ $(-)$ or 5:1(-- ). Samples were incubated at $37^{\circ} \mathrm{C}$ for the indicated times. Duplicate aliquots $(50 \mu \mathrm{l})$ were withdrawn from each phase and counted for radioactivity to determine palmitate distribution

\section{Statistical analysis}

Statistical analysis was performed according to the Student's t-test.

\section{Results}

\section{Palmitate binding to control and glucosylated serum albumin}

The binding of palmitate to albumin at equilibrium over a 10-fold range of Palmitate: HSA ratios is shown in Figure 1. Neither low $(0.1 \mathrm{molglc} / \mathrm{mol} \mathrm{HSA})$ or high ( $3 \mathrm{molglc} / \mathrm{mol} \mathrm{HSA}$ ) levels of glucosylation had an effect on the ability of human albumin to bind palmitate. As has been noted by other investigators [18], in small volumes in vitro the uptake of palmitate by albumin reaches a limiting level determined by the solubility of palmitate in the aqueous phase. In our system, this limiting level was about $2.5 \mathrm{~mol}$ palmitate/mol HSA.

The data depicted in Figure 1 reflect the binding of fatty acids to albumin at equilibrium $\left(24 \mathrm{~h}, 37^{\circ} \mathrm{C}\right)$. We also examined the kinetics of fatty acid binding to determine if glucosylation had any effect on the rate of palmitate binding to albumin. Despite the presence of $3 \mathrm{molglc} / \mathrm{mol} \mathrm{HSA}$ there was no difference in palmitate binding to control or glucosylated albumin (Fig. 2).

\section{The effect of albumin glucosylation on the uptake of palmitate by cells}

Even though glucosylation had no effect on the binding of at least $2 \mathrm{~mol}$ palmitate to human albumin, we speculated that the masking of lysine residues by glucose might interfere with recognition of the palmitate: HSA complex by cells and alter the transport of fatty acids into cells. Thus, we examined the uptake of palmitate by human erythrocytes and by HL-60 cells, a cultured human leukaemic cell line (Table 1).

The uptake of palmitate from glucosylated albumin did not differ from the uptake from native albumin in either erythrocytes or HL-60 cells. We next examined the intracellular distribution of palmitate into four in- 
Table 1. Effect of albumin glucosylation on the utilization of palmitate in erythrocyte and HL-60 cells

\begin{tabular}{|c|c|c|c|c|c|c|c|c|}
\hline & \multirow{2}{*}{\multicolumn{2}{|c|}{ Total uptake (nmol) }} & \multicolumn{6}{|c|}{ Distribution of palmitate ( $\%$ of total) } \\
\hline & & & \multicolumn{2}{|c|}{ Free palmitate } & \multicolumn{2}{|c|}{ Phospholipids } & \multicolumn{2}{|c|}{ Neutral lipids } \\
\hline & $15^{\prime}$ & $60^{\prime}$ & $15^{\prime}$ & $60^{\prime}$ & $15^{\prime}$ & $60^{\prime}$ & $15^{\prime}$ & $60^{\prime}$ \\
\hline \multicolumn{9}{|l|}{ Erythrocytes } \\
\hline Control HSA & $2.7 \pm 0.5$ & $2.7 \pm 0.2$ & $83.8 \pm 1.0$ & $74.4 \pm 1.0$ & $9.9 \pm 0.4$ & $19.7 \pm 0.4$ & $7.2 \pm 1.0$ & $9.2 \pm 2.0$ \\
\hline Glycosylated HSA & $2.7 \pm 0.7$ & $3.3 \pm 1.0$ & $86.9 \pm 2.0$ & $72.0 \pm 4.0$ & $8.6 \pm 1.0$ & $21.8 \pm 2.0$ & $6.3 \pm 0.5$ & $8.2 \pm 2.0$ \\
\hline \multicolumn{9}{|l|}{ HL-60 cells } \\
\hline Control HSA & $0.63 \pm 0.04$ & $1.6 \pm 0.25$ & $37.1 \pm 4.1$ & $32.6 \pm 3.1$ & $23.5 \pm 3.0$ & $28.3 \pm 3.2$ & $39.4 \pm 3.7$ & $39.1 \pm 4.1$ \\
\hline Glycosylated HSA & $0.79 \pm 0.08$ & $1.5 \pm 0.25$ & $42.4 \pm 4.6$ & $36.9 \pm 4.0$ & $20.8 \pm 2.4$ & $23.9 \pm 2.3$ & $36.7 \pm 2.8$ & $39.2 \pm 3.3$ \\
\hline \multicolumn{9}{|c|}{ Palmitate oxidation $(\mathrm{pmol} / \mathrm{h})$} \\
\hline Control HSA & $56.7 \pm 12.0$ & & & & & & & \\
\hline Glucosylated HSA & $52.6 \pm 9.1$ & & & & & & & \\
\hline
\end{tabular}

Erythrocytes $\left(2.0-2.3 \times 10^{9}\right.$ cells $)$ were incubated in $1 \mathrm{ml}$ isotonic phosphate buffered saline, $\mathrm{pH} 7.4$, containing $25 \mu \mathrm{mol} / \mathrm{palmitate}-14 \mathrm{C}-1$, $1950 \mathrm{cpm} / \mathrm{nmol}$, bound to albumin in a 2:1 palmitate: HSA complex. The glucosylated albumin contained 3 molglc/mol HSA. Values are the mean $\pm \mathrm{SD}$ of 4 observations.

$\mathrm{HL} / 60$ cells $\left(10^{6}\right.$ cells $/$ sample $)$ were incubated at $37^{\circ} \mathrm{C}$ in Iscove culture medium containing $10 \%$ fetal calf serum and $25 \mathrm{umol} / 11{ }^{14\{\mathrm{C}\}}$ palmitate, $6000 \mathrm{cpm} / \mathrm{nmol}$. Palmitate was bound to control or glucosylated albumin in a 2:1 complex. Glucosylated albumin contained $3 \mathrm{molglc} / \mathrm{mol}$ HSA. In the oxidation studies, incubation conditions were the same, except that the palmitate concentration was $12 \mu \mathrm{mol} / 1,30,000 \mathrm{cpm} / \mathrm{nmol}$. Observations are the mean $\pm \mathrm{SD}$ of 7 observations

tracellular pools: (1) the neutral lipids, (2) the phospholipids, (3) the free fatty acids, and (4) HL-60, the palmitate used for oxidation. Glucosylation of albumin did not affect the incorporation of palmitate into neutral lipids, phospholipids, or free fatty acids. In HL-60 cells no significant differences in palmitate oxidation were noted when the palmitate was derived from glucosylated or from control albumin.

\section{Discussion}

In plasma less than $0.1 \%$ of non-esterified fatty acids are free in solution. Rather, free fatty acids circulate as an fatty acid/albumin complex. Serum albumin has a great capacity to bind fatty acids and has at least three classes of binding sites for long chain fatty acids. For palmitate, there are 3 sites with strong affinity, 3 sites with moderate affinity, and more than 60 sites that bind palmitate very weakly [10]. In normal man, the palmitate levels in serum range from about $0.5 \mathrm{mmol} / \mathrm{l}$ after a fast to $2 \mathrm{mmol} / 1$ postprandially. The FA:HSA ratio is usually in the range of $0.5-2.0$.

The uptake of fatty acids from the FA: HSA complex is not well understood. Studies by Weisiger et al. [19] suggest that in liver a receptor on the outer cell membrane recognizes and binds the albumin portion of the FA: HSA complex. Only the fatty acid is transported into the cell, and the albumin carrier returns to the circulation to accept another fatty acid load.

In diabetes, lipid metabolism is markedly altered. Lipids are released from adipose tissue stores, blood lipid levels rise, and some tissues (e.g. heart and skeletal muscle) increasingly rely on fatty acids as fuels. In diabetic lipaemia, the FA: HSA ratio rises to 3-5 [20].
With these observations in mind, we investigated the effect of non-enzymatic glucosylation on the ability of albumin to bind palmitate. Other laboratories have reported that the binding of other ligands to albumin interferes with fatty acid binding [18, 21]. High levels of salicylates decrease fatty acid binding to albumin [21]. Heavily acetylated $(80-90 \%)$ albumin has much reduced affinity for palmitate [18]. These two modifications block amino groups of albumin just as non-enzymatic glucosylation does.

We were unable to detect any differences in palmitate binding due to glucosylation of serum albumin. While this study was in progress, Shaklai and co-workers [10] reported that glucosylated albumin has a 20 -fold lower affinity for cisparanaric acid, a fatty acid analogue that binds to the high affinity site of albumin [14]. The differences in binding were attributed to a conformational change in albumin induced by glucose binding. Our studies suggest that, even though a conformational change may occur in glucosylated albumin, its ability to bind and deliver a physiologically useful fatty acid are unimpaired.

In the data described here, human albumin was glucosylated to a level of 1-3 mol glucose per mol albumin. Studies from several laboratories [23] indicate that fresh human albumin from normal subjects is glucosylated to the level of about $0.25 \mathrm{~mol}$ glucose per mol albumin. In diabetic patients the value is two to three times higher $[22,23]$. Thus, our experiments suggest that glucosylation of albumin in vivo has a negligible effect on fatty acid binding, and plays no major role in altered lipid metabolism in diabetes.

Acknowledgments. This paper was supported by a generous gift from B. Weiss, without which the work would not have been possible. We thank Dr. J. F. Conscience for culturing the HL-60 cells, and for helpful discussion. 


\section{References}

1. Thorpe SR, Baynes JW (1982) Nonenzymatic glucosylation of proteins in vitro and in vivo. Horowitz MI, Pigman W (eds) The glycoconjugates, Vol 3. Academic Press, New York, pp 113-131

2. Bunn HF, Gabbay KH, Gallop PM (1978) The glycosylation of hemoglobin: relevence to diabetes mellitus. Science 200:21-27

3. Stevens VJ, Rouzer CA, Monnier VM, Cerami A (1978) Diabetic cataract formation: role of glycosylation of lens crystallines. PNAS (US) 75: 2918-2922

4. Trüeb B, Flückinger R, Winterhalter KH (1984) Nonenzymatic glycosylation of basement membrane collagen in diabetes mellitus. Coll. Rel Res 4: 239/251

5. Brownlee M, Vlassara H, Cerami A (1983) Nonenzymatic glycosylation reduces the susceptibility of fibrin to degradation by plasmin. Diabetes 32: 680/684

6. Witztum JL, Mahoney EM, Branks MJ, Fisher M, Elam RF, Steinberg D (1982) Nonenzymatic glycosylation of low density lipoproteins alters its biological activity. Diabetes 31: 283-291

7. Kennedy L, Baynes JW (1984) Nonenzymatic glycosylation and the chronic complications of diabetes: on overview. Diabetologia 26: 93-98

8. Flueckiger R, Winterhalter KH (1977) Glycosylated hemoglobin. Inserm 70: 319-326

9. Reed RG, Bacharack PS (1983) Location of the long chain fatty acid binding sites of bovine serum albumin. Fed Proc 42: 2157 (Abstract)

10. Shaklai, N, Garlick RL, Bunn HF (1984) Nonenzymatic glycosylation of human serum albumin alters its conformation and function. J Biol Chem 259: 3812-3817

11. Baynes JW, Thorpe SR, Murtiashaw MH (1984) Nonenzymatic glucosylation of lysine residues in albumin. In: Moldave K (ed) Methods in enzymology, Vol 106. Academic Press, New York, pp 88-98

12. Vaughan L, Fischer RW, Zimmermann DR, Winterhalter $\mathrm{KH}$ (1984) Nonenzymatic glucosylation of proteins: a new and rapid solution of proteins for in vitro investigations. FEBS Lett 173: 173-178

13. Spector AA, Jones K, Fletscher JE (1969) Binding of long-chain fatty acids to bovine serum albumin. J Lipid Res 10: 65-66
14. Demacker PNM, Hijmans AGM, Jansen AP (1982) Enzymic and chemical extraction determination of free fatty acids in serum compared. Clin Chem 28: 1765-1768

15. Gallagher R, Collins S, Jrujillo J, McCredie K, Ahearn M, Isai S, Metzger R, Aulakh G, Ting R, Ruscetti Z, Gallo R (1979) Characterization of the continuous differentiating myeloid cell line $(\mathrm{HL}$ $60)$ from a patient with acute promyelocytic leukemia. Blood 54: 713-733

16. Morand O, Fihack E, Gatt S (1982) Effect of albumin, low temperature, and metabolic inhibitors on transport of fatty acids into cultured human leukemic myeloid cells. Biochim Biophys Acta 693: $143-150$

17. Kelley TF (1968) Rapid assay of labeled free fatty acids in mixtures of labeled lipids. J Lipid Res 9: 799-800

18. Spector AG (1975) Fatty acid binding to plasma albumin. J Lipid Res 16: 165-179

19. Weisiger R, Gollan J, Ockner R (1981) Receptor for albumin on lines cell surface may mediate uptake of fatty acids and other albumin bound substances. Science 211: 1048-1050

20. Stauffacher W, Renold AE (1971) Pathophysiology of diabetes mellitus. In: Mashle A, White P, Bradley R, Krall L (eds) Joslins diabetes mellitus, 11th ed. Lea and Febiger, Philadelphia, pp 35-98

21. Dawkins PW, McArthur JN, Smith MJH (1970) The effect of sodium salicylate on the binding of long chain fatty acids to plasma proteins. J Pharm Pharmacol 22: 405-410

22. Schleicher E, Wieland OA (1981) Specific quantitation by high performance liquid chromatography of protein (lysine) bound glucose in human serum albumin and other glycosylated proteins. J Clin Chem Clin Biochem 19: 81-87

23. Dolhofer R, Wieland $\mathrm{OH}$ (1980) Increased glycosylation of serum albumin in diabetes mellitus. Diabetes 29: 417-422

Received: 6 February 1985

and in revised form: 23 April 1986

Dr. K. H. Winterhalter

Laboratorium für Biochemie I

Eidgenössische Technische Hochschule

CH-8092 Zürich

Switzerland 